\title{
PERLINDUNGAN HUKUM PENCATATAN LOGO SEBAGAI CIPTAAN SETELAH BERLAKUNYA UNDANG-UNDANG NOMOR 28 TAHUN 2014 TENTANG HAK CIPTA
}

\author{
Widowati Maria Teresa, Budi Santoso \\ Program Studi Magister Kenotariatan, \\ Fakultas Hukum, Universitas Diponegoro
}

\begin{abstract}
With the enactment of Law Number 28, 2014 About Copyright the creation of art in the form of a logo or distinctive sign is used as a brand in the trade of goods/services or used as a symbol of the organization, entity, or legal entities can not be recorded. Logo that cannot be registered as creation may be registered as trademarks and obtain trademarks protection. Associated with the unregistered logo in the List of Works does not reduce the copyrights protection of the logo, because the protection of the logo as Creation appears declaratively. Consequences of the unlisted logo in the List of Works are logo will not get an official passage on Creation. The government needs to tighten substantive and material checks on all works listed in the field of Intellectual Property Rights and the government may take the initiative to carry out dissemination and counselling accessible to the public especially for business practitioner.
\end{abstract}

Keywords : Logo, Legal Protection, Copyrights

Abstrak

Dengan diberlakukannya Undang-undang Nomor 28 Tahun 2014 Tentang Hak Cipta, seni lukis yang berupa logo atau tanda pembeda yang digunakan sebagai merek dalam perdagangan barang/jasa atau digunakan sebagai lambang organisasi, badan usaha, atau badan hukum tidak dapat dicatatkan. Logo yang tidak dapat dicatatkan sebagai Ciptaan dapat didaftarkan sebagai Merek dan mendapatkan perlindungan Merek. Terkait dengan tidak dicatatkannya logo dalam Daftar Ciptaan tidak mengurangi perlindungan Hak Cipta atas logo, karena perlindungan logo sebagai Ciptaan muncul secara deklaratif. Konsekuensi dari tidak dapat dicatatkannya logo dalam Daftar Ciptaan adalah Ciptaan logo tidak akan mendapatkan petikan resmi atas Ciptaan. Pemerintah perlu untuk memperketat pemeriksaan substantif maupun materiil terhadap seluruh karya yang didaftarkan di seluruh bidang Hak Kekayaan Intelektual dan dapat mengambil inisiatif untuk melakukan diseminasi dan penyuluhan yang dapat diakses secara mudah bagi masyarakat pada umumnya dan pelaku bisnis pada khususnya.

Kata kunci : Logo, Perlindungan Hukum, Hak Cipta

\section{A. Pendahuluan}

Salah satu perbedaan menarik yang ada di antara UU Hak Cipta 2002 dan UU Hak Cipta 2014 adalah adanya pembatasan pada pencatatan ciptaan sebagaimana yang dimaksud dalam Pasal 65 UU Hak Cipta 2014. "Pencatatan Ciptaan tidak dapat dilakukan terhadap seni lukis yang berupa logo atau tanda pembeda yang digunakan sebagai merek dalam perdagangan barang/jasa atau digunakan sebagai lambang organisasi, badan usaha, atau badan hukum.”

Asal kata logo dari Bahasa Yunani logos, yang berarti kata, pikiran, pembicaraan, akal budi. Pada awalnya yang lebih dulu populer adalah istilah logotype, bukan logo. Pertama kali istilah logotype muncul tahun 1810-1840, diartikan sebagai tulisan nama entitas yang didesain secara khusus dengan menggunakan teknik lettering atau memakai jenis huruf tertentu. Jadi awalnya logotype adalah elemen tulisan saja. Pada perkembangannya orang membuatnya makin unik / berbeda satu sama lain. Mereka mengolah huruf itu, menambahkan elemen gambar, bahkan 
tulisan dan gambar berbaur jadi satu, dan semua itu masih banyak yang menyebutnya dengan istilah logotype.

Fungsi logotype adalah sebagai berikut :

a. Identitas diri. Untuk membedakannya dengan identitas milik orang lain.

b. Tanda kepemilikan. Untuk membedakan miliknya dengan milik orang lain.

c. Tanda jaminan kualitas.

d. Mencegah peniruan/pembajakan.

Logo adalah penyingkatan dari logotype. Istilah logo baru muncul tahun 1937 dan kini istilah logo lebih populer daripada logotype. Logo bisa menggunakan elemen apa saja : tulisan, logogram, gambar, ilustrasi, dan lain-lain. Banyak juga yang mengatakan logo adalah elemen gambar/simbol pada identitas visual. Berdasarkan fungsi logo, maka kriteria utama logo adalah (Rustan, 2009):

a. Harus unik. Mencerminkan dan mengangkat citra entitasnya sekaligus membedakannya dengan yang lain.

b. Harus dapat mengakomodasi dinamika yang dialami entitasnya dalam jangka waktu selama mungkin. Artinya logo harus fleksibel sekaligus tahan lama.

\section{B. Metode Penelitian}

Metode penelitian yang digunakan adalah yuridis empiris, dengan spesifikasi penelitiannya secara deskriptif analitis. Sumber dan jenis datanya berupa data primer dan data sekunder, lalu teknik pengumpulan data diperoleh melalui studi lapangan dan studi kepustakaan. Teknik analisa datanya menggunakan analisis kualitatif

\section{Hasil dan Pembahasan}

1. Perlindungan Hukum Logo Sebagai Ciptaan Dalam UU Hak Cipta 2002 dan UU Hak Cipta 2014

Perkembangan teknologi informasi dan komunikasi telah menjadi salah satu variabel dalam Undang-Undang tentang Hak Cipta ini, mengingat teknologi informasi dan komunikasi di satu sisi memiliki peran strategic dalam pengembangan Hak Cipta, tetapi di sisi lain juga menjadi alat untuk pelanggaran hukum di bidang ini. Pengaturan yang proporsional sangat diperlukan, agar fungsi positif dapat dioptimalkan dan dampak negatifnya dapat diminimalkan.

Dengan memperhatikan hal tersebut maka perlu mengganti Undang-Undang Hak Cipta dengan yang baru, yang secara garis besar mengatur tentang :

a. Perlindungan Hak Cipta dilakukan dengan waktu lebih panjang sejalan dengan penerapan aturan di berbagai negara sehingga jangka waktu perlindungan Hak Cipta di bidang tertentu diberlakukan selama hidup pencipta ditambah 70 (tujuh puluh) tahun setelah Pencipta meninggal dunia.

b. Perlindungan yang lebih baik terhadap hak ekonomi para Pencipta dan/atau Pemilik Hak Terkait, termasuk membatasi pengalihan hak ekonomi dalam bentuk jual putus (sold flat).

c. Penyelesaian sengketa secara efektif melalui proses mediasi, arbitrase atau pengadilan, serta penerapan delik aduan untuk tuntutan pidana. 
d. Pengelola tempat perdagangan bertanggung jawab atas tempat penjualan dan/atau pelanggaran Hak Cipta dan/atau Hak Terkait di pusat tempat perbelanjaan yang dikelolanya.

e. Hak Cipta sebagai benda bergerak tidak berwujud dapat dijadikan objek jaminan fidusia.

f. Menteri diberi kewenangan untuk menghapus Ciptaan yang sudah dicatatkan, apabila Ciptaan tersebut melanggar norma agama, norma susila, ketertiban umum, pertahanan dan keamanan negara, serta ketentuan peraturan perundang-undangan.

g. Pencipta, Pemegang Hak Cipta, pemilik Hak Terkait menjadi anggota Lembaga Manajemen Kolektif agar dapat menarik imbalan atau Royalti.

h. Pencipta dan/atau pemilik Hak Terkait mendapat imbalan Royalti untuk Ciptaan atau produk Hak Terkait yang dibuat dalam hubungan dinas dan digunakan secara komersial.

i. Lembaga Manajemen Kolektif yang berfungsi menghimpun dan mengelola hak ekonomi Pencipta dan pemilik Hak Terkait wajib mengajukan permohonan izin operasional kepada Menteri.

j. Penggunaan Hak Cipta dan Hak Terkait dalam sarana multimedia untuk merespon perkembangan teknologi informasi dan komunikasi.

Dengan demikian sebelum berlakunya UU Hak Cipta 2014, terhadap Ciptaan dapat dilakukan pendaftaran untuk dicatat dalam Daftar Umum Ciptaan oleh Direktorat Jenderal, sedangkan dengan berlakunya UU Hak Cipta 2014, terhadap Ciptaan dapat dilakukan pencatatan dalam Daftar Umum Ciptaan oleh Menteri.

Perubahan istilah administrasi ini tidak merubah hakikat Hak Cipta sebagai suatu hak yang timbul sesaat setelah Ciptaan tersebut diciptakan, sehingga baik pendaftaran ataupun pencatatan tidak merupakan kewajiban untuk mendapatkan Hak Cipta.

Selaras dengan definisi Pasal 1 ayat 1 UU Hak Cipta 2014 Hak eksklusif pencipta timbul secara otomatis berdasarkan prinsip deklaratif setelah suatu ciptaan diwujudkan dalam bentuk nyata, sehingga seketika saat Ciptaan tersebut diwujudnyatakan, maka lahirlah Hak Pencipta atas Ciptaannya tersebut.

Untuk memperoleh pencatatan ciptaan di Kementerian Hukum dan Hak Asasi Manusia Republik Indonesia, pemohon dapat melakukan pengajuan permohonan melalui tiga alternatif, yaitu (Tim Visi Yustisia, 2015) :

a. Melalui Direktorat Jenderal Hak Kekayaan Intelektual (DJKI)

b. Melalui Kantor Wilayah Kementerian Hukum dan Hak Asasi Manusia Republik Indonesia di seluruh Indonesia, dan

c. Melalui Kuasa Hukum Konsultan HKI yang terdaftar.

Dengan diberlakukannya UU Hak Cipta 2014, perlindungan terhadap Hak Cipta khususnya logo lebih ditingkatkan dengan jangka waktu perlindungan yang lebih lama yaitu 70 tahun setelah Pencipta meninggal dunia.

Pelanggaran hak cipta adalah penggunaan karya yang dilindungi hak cipta, yang melanggar hak eksklusif pemegang hak cipta, seperti hak untuk mereproduksi, mendistribusikan, menampilkan atau memamerkan, atau membuat karya turunan tanpa seizin pemegang hak cipta. Penyelesaian perkara pelanggaran dan sengketa lainnya mengenai hak cipta dapat dilakukan melalui alternatif penyelesaian sengketa, arbitrase, atau pengadilan. Pengadilan yang berwenang menyelesaikan 
perkara pelanggaran dan lainnya mengenai hak cipta adalah pengadilan niaga. Selain pelanggaran hak cipta atau hak terkait dalam bentuk pembajakan, sepanjang para pihak yang bersengketa diketahui keberadaannya atau berada di wilayah NKRI, diutamakan harus menempuh penyelesaian sengketa melalui mediasi sebelum melakukan tuntutan pidana.

Pencipta, pemegang hak cipta, atau pemilik hak terkait yang mengalami kerugian hak ekonomi atas pelanggaran hak cipta berhak mengajukan gugatan kepada pengadilan niaga dan memperoleh ganti rugi. Gugatan ganti rugi dapat berupa permintaan untuk menyerahkan seluruh atau sebagian penghasilan yang diperoleh dari penyelenggaraan ceramah, pertemuan ilmiah, atau pameran karya yang merupakan hasil dari pelanggaran hak cipta. Ganti rugi tersebut harus dibayarkan paling lama 6 (enam) bulan setelah putusan pengadilan yang berkekuatan hukum tetap.

Selain gugatan, pencipta, pemegang hak cipta, atau pemilik hak terkait dapat memohon putusan provisi atau putusan sela kepada pengadilan niaga untuk :

a. meminta penyitaan atas ciptaan yang telah dilakukan pengumuman atau penggandaan, atau alat penggandaan yang digunakan untuk menghasilkan ciptaan hasil pelanggaran hak cipta, dan

b. menghentikan kegiatan pengumuman pendistribusian, komunikasi, atau penggandaan ciptaan yang merupakan hasil pelanggaran hak cipta.

Berdasarkan Pasal 100 UU Hak Cipta 2014, tata cara gugatan atas pelanggaran hak cipta, sebagai berikut :

a. gugatan diajukan kepada ketua pengadilan niaga,

b. gugatan dicatat oleh panitera pengadilan niaga dalam register perkara pengadilan pada tanggal gugatan tersebut didaftarkan,

c. panitera pengadilan niaga memberikan tanda terima yang telah ditandatangani pada tanggal yang sama dengan tanggal pendaftaran,

d. panitera pengadilan niaga menyampaikan permohonan gugatan kepada ketua pengadilan niaga dalam waktu paling lama 2 (dua) hari terhitung sejak tanggal gugatan didaftarkan,

e. dalam waktu paling lama 3 (tiga) hari terhinung sejak tanggal gugatan didaftarkan, pengadilan niaga menetapkan hari sidang,

f. pemberitahuan dan pemanggilan para pihak dilakukan oleh juru sita dalam waktu paling lama 7 (tujuh) hari terhitung sejak gugatan didaftarkan.

Putusan pengadian niaga harus diucapkan dalam sidang terbuka untuk umum. Putusan tersebut harus diucapkan paling lama 90 (sembilan puluh) hari sejak gugatan didaftarkan. Jika jangka waktu sebagaimana tersebut tidak dapat dipenuhi, atas persetujuan Ketua Mahkamah Agung, jangka waktu tersebut dapat diperpanjang selama 30 (tiga puluh) hari. Sementara itu, juru sita harus menyampaikan putusan pengadilan niaga kepada para pihak paling lama 14 (empat belas) hari sejak putusan dibacakan.

Atas permintaan pihak yang merasa dirugikan karena pelaksanaan hak cipta, pengadilan niaga dapat mengeluarkan penetapan sementara untuk :

a. mencegah masuknya barang yang diduga hasil pelanggaran hak cipta ke jalur perdagangan,

b. menarik dari peredaran, menyita, dan menyimpan sebagai alat bukti hal-hal yang berkaitan dengan pelanggaran hak cipta tersebut,

c. mengamankan barang bukti dan mencegah penghilangannya oleh pelanggar, dan

d. menghentikan pelanggaran guna mencegah kerugian yang lebih besar. 
Permohonan penetapan sementara ini diajukan secara tertulis oleh pencipta, pemegang hak cipta, pemilik hak terkait, atau kuasanya kepada pengadilan niaga dengan melampirkan bukti kepemilikan hak cipta dan bukti pelanggaran, serta membayar jaminan yang besarnya sebanding dengan nilai barang yang akan dikenai penetapan sementara.

Setiap orang yang terbukti melakukan pelanggaran terhadap perlindungan hak cipta dikenakan sanksi sesuai yang diatur dalam Bab XVII UU Hak Cipta 2014. Tindak pidana sebagaimana dimaksud dalam UU Hak Cipta 2014 merupakan delik aduan.

Paparan di atas menjelaskan mengenai perlindungan hukum preventif dan represif terhadap Ciptaan setelah berlakunya UU Hak Cipta 2014. Diharapkan dengan adanya perubahan ketentuanketentuan tersebut dapat mengakomodasi perkembangan ilmu pengetahuan, teknologi, seni dan sastra yang sudah demikian pesat.

\section{Pencatatan Logo Yang Digunakan Sebagai Merek Setelah Berlakunya UU Hak Cipta 2014}

Pasal 65 UU Hak Cipta 2014 menyebutkan bahwa : "Pencatatan Ciptaan tidak dapat dilakukan terhadap seni lukis yang berupa logo atau tanda pembeda yang digunakan sebagai merek dalam perdagangan barang/jasa atau digunakan sebagai lambang organisasi, badan usaha, atau badan hukum.” Dalam Penjelasan Pasal 65 UU Hak Cipta 2014 disebutkan “cukup jelas”.

Hal ini tentu menimbulkan pertanyaan mengapa seni lukis yang berupa logo atau tanda pembeda yang digunakan sebagai merek dalam perdagangan barang/jasa atau digunakan sebagai lambang organisasi, badan usaha, atau badan hukum tidak dapat dicatatkan, karena berdasarkan Pasal 40 huruf f UU Hak Cipta 2014, "gambar" merupakan jenis ciptaan yang dilindungi, lebih lanjutnya di Penjelasan Pasal 40 disebutkan bahwa yang dimaksud dengan "gambar" antara lain motif, diagram, sketsa, logo, unsur-unsur warna dan bentuk huruf indah.

Untuk menjawab pertanyaan tersebut haruslah ditilik kembali bagaimana perlindungan logo yang digunakan sebagai merek sebelum berlakunya UU Hak Cipta 2014. Logo sebagai identitas dan tanda kepemilikan merupakan hal yang dianggap penting bagi penyedia barang/jasa yang ada di masyarakat dewasa ini. Sebuah logo merupakan tanda jaminan kualitas bagi konsumen dan oleh karenanya digunakan sebagai merek dalam perdagangan barang/jasa.

Menurut Undang-undang Nomor 15 Tahun 2001 Tentang Merek selanjutnya disebut UU Merek 2001, Merek sendiri didefinisikan sebagai tanda yang berupa gambar, nama, kata, hurufhuruf, angka-angka, susunan warna, atau kombinasi dari unsur-unsur tersebut yang memiliki daya pembeda dan digunakan dalam kegiatan perdagangan barang atau jasa.

Definisi yang diberikan oleh Pasal 1 UU Merek 2001 tersebut tentu mengingatkan kita akan hakikat logo sebagai tanda pembeda yang dapat merupakan gabungan antara huruf, lambang, angka dengan susunan warna dan bentuk yang unik. Karena definisi merek yang merujuk kepada logo tersebut, maka masyarakat kerap kali tidak memahami apakah logo harus didaftarkan sebagai merek atau hak cipta sehingga hanya didaftarkan pada satu perlindungan hak saja.

Kepemilikan atas merek dapat menimbulkan masalah di kemudian hari apabila pemilik merek tidak mendaftarkan logo untuk mendapatkan perlindungan hak cipta sekaligus. Bisa saja terjadi logo didaftarkan sebagai merek oleh seseorang sementara ada juga orang lain mendaftarkannya sebagai hak cipta. Hal inilah yang mendasari pembuat Undang-undang untuk 
memasukkan larangan pencatatan hak cipta atas logo atau tanda pembeda yang digunakan sebagai merek dalam perdagangan barang/jasa atau digunakan sebagai lambang organisasi, badan usaha, atau badan hukum. Diharapkan dengan adanya larangan ini, logo yang telah dipakai sebagai merek tidak akan didaftarkan pihak lain dalam perlindungan Hak Cipta.

Dalam UU Merek dan Indikasi Geografis 2016, istilah logo telah disebutkan secara terang dalam definisi merek itu sendiri. Pasal 1 ayat 1 mendefinisikan merek sebagai tanda yang dapat ditampilkan secara grafis berupa gambar, logo, nama, kata, huruf, angka, susunan warna, dalam bentuk 2 (dua) dimensi dan/atau 3 (tiga) dimensi, suara, hologram, atau kombinasi dari 2 (dua) atau lebih unsur tersebut untuk membedakan barang dan/atau jasa yang diproduksi oleh orang atau badan hukum dalam kegiatan perdagangan barang dan/atau jasa.

Ditegaskan kembali di dalam Pasal 2 ayat 3 bahwa Merek yang dilindungi terdiri atas tanda berupa gambar, logo, nama, kata, huruf, angka, susunan warna, dalam bentuk 2 (dua) dimensi dan/atau 3 (tiga) dimensi, suara, hologram, atau kombinasi dari 2 (dua) atau lebih unsur tersebut untuk membedakan barang dan/atau jasa yang diproduksi oleh orang atau badan hukum dalam kegiatan perdagangan barang dan/atau jasa.

Pengertian merek sendiri menyebutkan bahwa merek yang dilindungi adalah tanda untuk membedakan barang dan/atau jasa yang diproduksi oleh orang atau badan hukum dalam kegiatan perdagangan barang dan/atau jasa. Tampak jelas dalam definisi ini bahwa perlindungan Merek dimaksudkan untuk melindungi produk dalam kegiatan perdagangan, sehingga hak yang terkandung dalam perlindungan merek adalah hak ekonomi. Berbeda dengan Hak Cipta yang merupakan hak ekslusif yang terdiri atas Hak Moral dan Hak Ekonomi. Hak Moral melekat secara abadi pada diri Pencipta sedangkan Hak Ekonomi merupakan hak untuk mendapatkan manfaat ekonomi atas Ciptaan.

Hal lain yang membedakan perlindungan hak antara hak cipta dan merek adalah bahwa hak atas merek baru diperoleh setelah Merek tersebut terdaftar. Lain halnya dengan hak cipta yang timbul perlindungannya setelah Ciptaan tersebut dibuat.

Dalam pendaftaran Merek dikenal adanya pemeriksaan substanstif. Pemeriksaan substantif merupakan pemeriksaan yang dilakukan oleh Pemeriksa terhadap Permohonan pendaftaran Merek dengan mempertimbangkan keberatan dan/atau sanggahan yang dilakukan dalam jangka waktu pengumuman.

Keberatan dapat diajukan jika terdapat alasan yang cukup disertai bukti bahwa Merek yang dimohonkan pendaftarannya adalah Merek yang berdasarkan UU Merek dan Indikasi Geografis 2016 tidak dapat didaftar atau ditolak. Jadi jika dalam masa pengumuman ada pihak yang merasa bahwa suatu merek tersebut mempunyai persamaan pada pokoknya atau keseluruhannya dengan merek miliknya maka dapat mengajukan keberatan secara tertulis kepada Menteri.

Pada proses penyelesaian sengketa di Pengadilan, para pihak dapat meminta pengadilan untuk mengeluarkan penetapan sementara. Hal-hal yang dapat dimintai penetapan tersebut adalah untuk hal-hal sebagaimana diatur dalam Pasal 106 UU Hak Cipta 2014. Ketentuan yang menjadi permasalahan yuridis dalam permintaan penetapan di Pengadilan adalah terkait dengan persyaratan yang harus dipenuhi. Di antara syarat yang harus dipenuhi adalah melampirkan bukti kepemilikan hak cipta. Hal tersebut diatur dalam Pasal 107 UU Hak Cipta 2014. Pembuktian tersebut sulit 
dilakukan oleh pihak yang merasa dirugikan. Hal ini karena pihak yang merasa dirugikan tidak mempunyai petikan pemegang hak, karena tidak boleh dicatatkan. Bukti apa yang harus ditunjukkan juga tidak jelas. Peraturan perundang-undangan ini tidak menyediakan solusi terkait pembuktian kepemilikan hak cipta logo yang tidak bisa dicatatkan.

Persoalan semacam ini yang masih menimbulkan tanda tanya bagi masyarakat. Bisa dikatakan salah satu penyebab masih banyaknya kasus pelanggaran hak cipta adalah ketidakjelasan peraturan yang ada dan tidak disertainya peraturan perundang-undangan dengan peraturan pelaksananya.

Selain karena kurang jelasnya peraturan yang ada, kurangnya pemahaman terhadap arti dan fungsi hak cipta, serta ketentuan undang-undang hak cipta pada umumnya, masih kurangnya penyuluhan mengenai hal tersebut juga merupakan salah satu faktor penting untuk terwujudnya perlindungan hukum.

Pendidikan hukum secara umum yang ditujukan kepada seluruh masyarakat dalam bentuk diseminasi dan penyuluhan hukum merupakan hal penting dalam menciptakan budaya hukum masyarakat. Proses edukasi dan pembudayaan hukum harus dilakukan terhadap semua lapisan baik penyelenggara negara, aparatur penegak hukum maupun masyarakat pada umumnya.

Sejalan dengan pengarahan Presiden RI, bahwa seluruh penyelenggara negara bertanggung jawab terhadap terdiseminasikannya hukum kepada seluruh lapisan masyarakat sehingga mas yarakat memahami hukum secara utuh yang secara langsung merupakan langkah preventif agar tidak terjadi pelanggaran hukum. Pelanggaran hukum yang terjadi karena lemahnya diseminasi dan penyuluhan hukum menjadi bagian dari tanggung jawab penyelenggara negara.

Pelaksanaan diseminasi dan penyuluhan hukum adalah unsur yang tidak dapat dipisahkan dari penerapan asas fiksi hukum yang menyatakan bahwa "setiap orang dianggap tahu hukum". Penerapan asas fiksi hukum tanpa dukungan sosialisasi hukum yang baik dapat berakibat tidak terlindunginya masyarakat itu sendiri karena masyarakat dapat terjebak dalam pelanggaran yang mungkin dia tidak ketahui dan kehendaki.

Dari pengalaman yang selama ini berlangsung dapat disimpulkan bahwa sosialisasi hukum merupakan salah satu yang perlu dengan sungguh-sungguh ditingkatkan melalui koordinasi secara nasional, terpola dan terstruktur secara baik dengan memanfaatkan seluruh infrastruktur pendukung seperti partisipasi aktif masyarakat, media elektronik maupun non elektronik serta saluran-saluran lainnya seperti pemanfaatan teknologi informasi dan lain-lain.

Tindakan law enforcement dalam semua sektor hukum harus selalu dibarengi dengan upaya preventif berbentuk sosialisasi produk-produk hukum. Berhasilnya upaya preventif sehingga tidak terjadi atau terkuranginya pelanggaran hukum akan lebih maslahat dan tidak menimbulkan kerugian yang lebih besar dibandingkan dengan upaya represif setelah terjadinya pelanggaran.

Sosialisasi dalam bentuk diseminasi dan penyuluhan hukum dalam rangka menciptakan budaya hukum masyarakat merupakan tugas pemerintah. Dengan demikian penegak hukum dapat melaksanakan fungsi law enforcement sekaligus pengayoman, sesuai dengan tujuan hukum, yaitu keadilan dan ketertiban, karena fungsi hukum itu sendiri selain sebagai pencipta keteraturan (order), juga harus dapat memberikan perlindungan bagi rakyat untuk memperoleh keadilan dan bukan untuk menyengsarakan.(Jaya, 2016) 
Pada masa kini dimana perkembangan teknologi dan informasi bergerak sangat cepat, pemerintah kiranya dapat mengambil inisiatif untuk melakukan diseminasi dan penyuluhan dalam bentuk-bentuk yang memanfaatkan teknologi seperti media sosial, website atau jurnal-jurnal yang dapat diakses secara mudah bagi masyarakat. Sehingga fiksi hukum "setiap orang dianggap tahu hukum" bisa digantikan dengan ungkapan "setiap orang tahu hukum".

Kiranya pemerintah dapat mengambil langkah ke depannya untuk lebih memasyarakatkan hukum dan bukan hanya sekedar menciptakan hukum, sehingga cita-cita hukum itu sendiri dapat tercapai.

Terkait masalah perlindungan logo dalam bidang hak kekayaan intelektual, sebaiknya pemerintah membuat aturan yang lebih jelas terhadap bentuk perlindungan hukum yang diberikan baik dalam ranah hak cipta atau dalam ranah merek. Mengingat perlindungan hak cipta atas logo timbul sejak diciptakan maka perlindungan hukum terhadap logo tetap harus dipertahankan dengan menambah klausul mengenai pembuktian hak cipta atas logo tersebut. Pemerintah juga perlu untuk memperketat pemeriksaan substantif maupun materiil terhadap seluruh karya yang didaftarkan di seluruh bidang Hak Kekayaan Intelektual terutama di bidang Merek dan Hak Cipta.

Tidak berhenti sampai disitu, diseminasi dan penyuluhan terhadap setiap perubahan yang ada dalam ketentuan perundang-undangan di bidang Hak Kekayaan Intelektual sebaiknya mulai dilaksanakan dengan sungguh-sungguh sehingga masyarakat pada umumnya dapat tepat memahami dan melaksanakan hak dan kewajibannya di bidang Kekayaan Inteletual.

\section{Simpulan}

1. UU Hak Cipta 2014 timbul karena perkembangan ilmu pengetahuan dan teknologi yang sedemikian pesat, di samping memberikan dampak positif juga memberikan dampak negatif. Kasus pembajakan Ciptaan yang terjadi dimana-mana dinilai sangat mengkhawatirkan sehingga Pemerintah mengubah ketentuan-ketentuan yang ada dalam UU Hak Cipta 2002. Diharapkan jaminan perlindungan hukum dan kepastian hukum dapat terlaksana.

Perlindungan hukum preventif dalam UU Hak Cipta 2014 dengan adanya pengaturan yang lebih rinci mengenai Hak Moral dan Hak Ekonomi Pencipta, Pemegang Hak Cipta dan Pemilik Hak Terkait serta Perlindungan Hak Cipta dilakukan dengan waktu lebih panjang.

Perlindungan hukum represif dalam UU Hak Cipta 2014 dengan adanya pemberian sanksi pidana, alternatif penyelesaian sengketa melalui proses mediasi, arbitrase atau pengadilan, serta penerapan delik aduan untuk tuntutan pidana.

2. Hal yang melatarbelakangi timbulnya aturan tidak dicatatkannya logo yang digunakan sebagai merek dalam perdagangan barang/jasa atau digunakan sebagai lambang organisasi, badan usaha, atau badan hukum adalah bahwa masyarakat dalam hal ini pelaku usaha penyedia barang/jasa tidak menyadari bahwa logo merupakan ciptaan yang dapat dilindungi oleh Hak Cipta dan hanya mendaftarkannya di Merek. Sehingga dimungkinkan pihak lain untuk mendaftarkan logo yang sama dalam Hak Cipta.

Logo yang tidak dapat dicatatkan sebagai Ciptaan dapat didaftarkan sebagai Merek dan mendapatkan perlindungan Merek. 
Terkait dengan tidak dicatatkannya logo dalam Daftar Ciptaan tidak mengurangi perlindungan Hak Cipta atas logo, karena perlindungan logo sebagai Ciptaan muncul secara deklaratif. Konsekuensi dari tidak dapat dicatatkannya logo dalam Daftar Ciptaan adalah Ciptaan logo tidak akan mendapatkan petikan resmi atas Ciptaan. Jika terjadi sengketa atas logo tersebut, akan susah dibuktikan siapa Pencipta pertama yang menciptakan logo tersebut. Terlepas dari apakah logo tersebut merupakan merek yang telah terdaftar atau tidak, pembuktian untuk sengketa akan sulit dilakukan jika Pencipta tidak mempunyai dokumentasi yang rapi terhadap logo yang diciptakannya.

\section{Daftar Pustaka}

Nyoman Serikat Putra Jaya. 2016, Politik Hukum. Semarang: Badan Penerbit Universitas Diponegoro.

Surianto Rustan. 2009. Mendesain Logo. Jakarta: PT Gramedia Pustaka Utama.

Tim Visi Yustisia. 2015. Panduan Resmi Hak Cipta (Dari Mendaftar, Melindungi, hingga Menyelesaikan Sengketa). Jakarta: Visi Media. 